\title{
Occupational Safety and Health Officials' Perception of Safety and Health Education for Business Owners
}

\author{
Myeong-Gu Lee ${ }^{1}$, Myeong-Jin Jeong*2, Shi-Hyun Park ${ }^{3}$, Eun-Joo Kim ${ }^{4}$

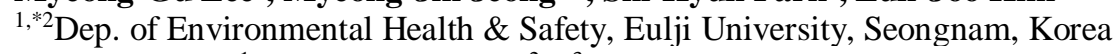 \\ lmg@eulji.ac.kr ${ }^{1}$,jmj123@eulji.ac.kr², ${ }^{3}$ Dep. of Industrial Safety Engineering, Yuhan University, Inchen, \\ Koreaspark@yuhan.ac.kr ${ }^{3},{ }^{4}$ Faculty of Liberal Arts, Eulji University, Seongnam, Korea kej70@eulji.ac.kr ${ }^{4}$
}

Article History: Received: 11 January 2021; Accepted: 27 February 2021; Published online: 5 April 2021

\begin{abstract}
This study was intended to provide basic data for discussion on the introduction of safety and health education system for business owners to prevent industrial accidents. To this end, a questionnaire survey was conducted on 548 occupational safety and health officials, of which $86.7 \%$ expected that the introduction of safety and health education for business owners would be very helpful in preventing accidents in the workplace. On the other hand, it was pointed out that the effectiveness of safety and health education for business owners needs to be raised as it deals with the areas considered to be important in the job and basic competencies of business owners. The study subjects also most highly agreed with the need for annual regular training for business owners at all workplaces.
\end{abstract}

Keywords: Industrial accidents, Safety and health education, Business owner, Disaster preventio

\section{Introduction}

While the national industrial accident rate has gradually decreased for the last 10 years, from 0.71 in 2008 to 0.54 in 2018, thanks to the efforts of the government and industrial sites, the number of industrial accident victims has not declined but rather has shown a slight rise, with about 100,000 victims every year [1, 2]. The rise in the number of industrial accident victims despite the decreased accident rate suggests that the numbers of workplaces and workers are increasing $[1,2]$ and that stronger efforts to reduce accidents are required as the efficiency of the existing measures may gradually diminish.

Meanwhile, many preceding studies have reported that safety and health education introduced to reduce industrial accidents is highly effective in reducing the incidence rate of industrial accidents [3, 4, 5]. Although the Occupational Safety and Health Act prescribes that safety and health education must be carried out for the persons in charge of management, workers, management supervisors, safety managers, health managers, safety and health managers, etc. [6,9], education for business owners, which is the most important for accident prevention, is not mandatory under the act. There is only a provision on lowering the premium rate of industrial accident compensation insurance for workplaces where business owners have completed the related education and established industrial prevention plans that are recognized by the relevant authorities in Article 15 (Special Cases of Premium Rate) of the Act on the Collection, Etc. of Premiums for Employment Insurance and Industrial Accident Compensation Insurance [7]. Notably, when the Occupational Safety and Health Act was amended in January 1900, Article 32 (Education for Business Owners) was newly included; however, as regulations on occupational safety and health were greatly relaxed later, the act was amended once again (Act No. 8562, July 27, 2007, Partial Amendment) with the deletion of the provision related to education as penalties on business owners (Article 32, Paragraph 1, Subparagraph 4), as part of efforts to remove the regulations that lacked feasibility to enhance the industrial accident prevention effects of the act.

The safety and health management policy of a business site, which is closely related to the management philosophy on safety, is established based on the safety awareness of the business owner. It is well known that this policy covers and affects all areas related to compliance with the Occupational Safety and Health Act, safety and health plan establishment, and the composition and operation of a safety and health management organization [8]

Therefore, this study aims at providing valid data for discussion on the introduction of safety and health education system for business owners by conducting a survey for occupational safety and health officials about their expectation level on industrial accident prevention effect by the introduction of such system, their perception of competencies required of business owners, the target group of education, and adequate education cycle for the development of educational programs

\section{Study Methods}

\subsection{Study Subject and Data Collection}

To gather opinions from industrial sites on the introduction of safety and health education for business owners, this study conducted data collection via a survey for over two months from July 2 to September 10, 2018 with business owners and management supervisors mostly from workplaces where safety and health education for them have been provided by institutions designated by the Ministry of Employment and Labor. The survey 
was carried out on the study subjects' expectation level on industrial accident prevention effect by the introduction of safety and health education system for business owners, their perception of competencies required of business owners, the target groups of education, and adequate education cycle. A total of 548 copies of the questionnaire were retrieved, and 453 of them were used for analysis after the exclusion of 95 copies due to insufficient information.

\subsection{Data Analysis}

To fulfill the purpose of this study, the collected data were analyzed with the PASW Statistics 18.0 program. First, the Cronbach' $\alpha$ coefficient was calculated to assess the internal consistency of the survey tool. The Cronbach' $\alpha$ coefficient of the entire survey tool was .904, indicating a high level of reliability. To understand the general characteristics of the study subjects, frequencies and percentages were calculated and descriptive statistics were conducted to explain the collected data. In addition, an independent sample t-test and a one-way ANOVA (analysis of variance) were conducted to analyze differences in perception depending on the general characteristics of the study subjects. Lastly, Scheffe was conducted as a post-hoc test

\subsection{Survey Results}

\subsubsection{General Characteristics of the Respondents}

Among the subjects, males outnumbered females by $85.7 \%$ to $14.3 \%$, and the largest age group (35.5\%) was those in their $40 \mathrm{~s}$. The business category with the largest number of respondents was manufacturing $(48.8 \%)$. The largest proportion of respondents' workplaces (32.9\%) were classified as SMEs with 1-49 workers. The most common position among the respondents was management supervisor, with a percentage of $43.7 \%$. In terms of work experience, those with a career of 6-10 years (19.4\%) accounted for the largest proportion of all respondents.

\subsubsection{Expectation Level on Industrial Accident Prevention Effect}

The survey also assessed the respondents' expectation level on industrial accident prevention effect by the introduction of safety and health education system for business owners. The results are as shown in $\langle$ Table 1 $\rangle$.

$<$ Table 1> Expectation Level on Industrial Accident Prevention Effect by the Introduction of Education System for Business Owners ( $\mathrm{N}=453)$

\begin{tabular}{|c|c|c|c|c|c|c|}
\hline $\begin{array}{l}\text { Expectation } \\
\text { level on } \\
\text { industrial } \\
\text { accident } \\
\text { prevention } \\
\text { effect }\end{array}$ & $\begin{array}{l}\text { Frequency } \\
\text { (person) }\end{array}$ & $\begin{array}{l}\text { Percentage } \\
(\%)\end{array}$ & Mean & $\begin{array}{l}\text { Standard } \\
\text { deviation }\end{array}$ & Skewness & Kurtosis \\
\hline Very low & 1 & 2 & \multirow{5}{*}{4.29} & \multirow{5}{*}{.789} & \multirow{5}{*}{-.996} & \multirow{5}{*}{.719} \\
\hline Low & 12 & 2.6 & & & & \\
\hline Neutral & 52 & 11.5 & & & & \\
\hline High & 178 & 39.3 & & & & \\
\hline Very high & 210 & \begin{tabular}{|l|}
46.4 \\
\end{tabular} & & & & \\
\hline
\end{tabular}

According to the survey results on the respondents' expectation level on accident prevention effect by the introduction of safety and health education system for business owners, the groups with "high" and "very high" expectation accounted for $39.3 \%$ and $46.4 \%$, respectively, totaling $85.7 \%$, which is a very large portion of the total respondents. In addition, the average (standard deviation) of the expectation level was also as high as 4.29 (.789). It is thus considered that the respondents expect the introduction of education system for business owners to be very helpful in preventing accidents in the workplace.

As a result of analyzing differences in the respondents' expectation level on industrial accident prevention effect depending on their general characteristics, it was found that differences according to general characteristics factors except for age were statistically insignificant. In terms of age, however, the group in their 50s showed the highest expected level mean (standard deviation) of 4.43 (.726) on industrial accident prevention effect compared to other age groups. The difference was statistically significant at the significance level of .05 $(\mathrm{F}=3.119, \mathrm{p}=.015)$. These results suggest that all groups of the respondents, regardless of their general characteristics, expect the introduction of education system for business owners to be effective in preventing industrial accidents.

$<$ Table 2> Differences in Expectation Level Depending on the Respondents' General Characteristics $(\mathrm{N}=453)$

\begin{tabular}{|c|c|c|c|c|c|c|}
\hline \multicolumn{2}{|c|}{ Variable } & Frequenc & $\bar{M}$ & Standard & $\mathrm{t} / \mathrm{F}$ & $\mathrm{p}$ \\
\hline \multirow[t]{2}{*}{ Gender } & Male & 388 & 4. & .776 & \multirow{2}{*}{$\begin{array}{c}2.3 \\
56\end{array}$} & \multirow{2}{*}{019} \\
\hline & Female & 65 & $\begin{array}{c}4 . \\
08^{4} \\
\end{array}$ & .835 & & \\
\hline Age & $20 \mathrm{~s}^{\mathrm{a}}$ & 48 & 4. & .771 & 3.1 & \\
\hline
\end{tabular}




\begin{tabular}{|c|c|c|c|c|c|c|}
\hline & & & 29 & & \multirow[t]{5}{*}{$19 *$} & \multirow{5}{*}{$\mathrm{Pe}^{015}$} \\
\hline & $30 s^{b}$ & 121 & 21. & .798 & & \\
\hline & $40 s^{c}$ & 161 & 32. & .771 & & \\
\hline & $50 s^{d}$ & 101 & 43 & .726 & & \\
\hline & 60 s or over ${ }^{\mathrm{e}}$ & 22 & $82^{3 .}$ & 1.006 & & \\
\hline \multirow[t]{6}{*}{$\begin{array}{l}\text { Business } \\
\text { category }\end{array}$} & Manufacturing & 221 & 32 & .810 & \multirow[t]{6}{*}{$7^{.41}$} & \multirow[t]{6}{*}{837} \\
\hline & Service industry & 72 & 28. & .736 & & \\
\hline & Construction & 44 & $\begin{array}{c}4 . \\
27\end{array}$ & .817 & & \\
\hline & $\begin{array}{l}\text { Industrial accident prevention } \\
\text { organization }\end{array}$ & 39 & 26 & .715 & & \\
\hline & $\begin{array}{l}\text { Safety and health } \\
\text { educationinstitution }\end{array}$ & 12 & 00. & .603 & & \\
\hline & Other & 65 & 28 & .839 & & \\
\hline \multirow{4}{*}{$\begin{array}{l}\text { Size of the } \\
\text { workplace } \\
\text { (number of } \\
\text { employees) }\end{array}$} & 1-49 employees & 149 & $\begin{array}{c}4 . \\
17\end{array}$ & .817 & \multirow[t]{4}{*}{$\begin{array}{l}2.0 \\
80\end{array}$} & \multirow[t]{4}{*}{102} \\
\hline & 50-299 employees & 124 & 30. & .796 & & \\
\hline & 300-499 employees & 41 & $41^{4}$ & .741 & & \\
\hline & 500 or more employees & 139 & $37^{4}$ & .754 & & \\
\hline \multirow[t]{5}{*}{ Position } & Management supervisor & 198 & 33. & .754 & \multirow[t]{5}{*}{$\begin{array}{l}1.1 \\
66\end{array}$} & \multirow[t]{5}{*}{325} \\
\hline & Safety and health manager & 125 & 26. & .824 & & \\
\hline & $\begin{array}{l}\text { Person in charge of safety and } \\
\text { health management }\end{array}$ & 13 & 92. & 1.038 & & \\
\hline & Business owner & 8 & 00. & .756 & & \\
\hline & Other & 109 & 30. & .776 & & \\
\hline
\end{tabular}

$* P<.05$

\subsubsection{Education Target Group}

According to the survey results on the perception of the target group of safety and health education for business owners, 277 respondents chose "business owners at all workplaces," accounting for the largest percentage $(61.1 \%)$.

A total of 277 respondents selected "business owners at all workplaces" as the target group of safety and health education for business owners, taking up the largest proportion of all respondents. There were statistically significant differences in their perception of the target group depending on their business categories, which is one of the general characteristic factors. In particular, the respondent group engaged in the service industry had the largest proportion of those who chose "business owners at all workplaces" (69.4\%) compared to other business category groups. 
<Table 4> Differences in the Perception of the Safety and Health Education Target Group Depending on

Business Categories ( $\mathrm{N}=453)$

\begin{tabular}{|c|c|c|c|c|c|c|c|}
\hline $\begin{array}{l}\text { Business } \\
\text { category }\end{array}$ & $\begin{array}{l}\text { Classific } \\
\text { ation }\end{array}$ & $\begin{array}{r}\text { Business } \\
\text { owners at all } \\
\text { workplaces }\end{array}$ & $\begin{array}{c}\text { Business owners } \\
\text { at workplaces with } \\
\text { poor industrial } \\
\text { accident } \\
\text { management }\end{array}$ & $\begin{array}{c}\text { Business } \\
\text { owners at } \\
\text { autonomously } \\
\text { participating } \\
\text { workplaces }\end{array}$ & $\begin{array}{c}\text { Business } \\
\text { owners at small } \\
\text { and medium- } \\
\text { sized workplaces }\end{array}$ & $\begin{array}{l}\text { Business owners } \\
\text { at fully } \\
\text { autonomously } \\
\text { participating } \\
\text { workplaces }\end{array}$ & $\begin{array}{l}\text { To } \\
\text { tal }\end{array}$ \\
\hline \multirow{2}{*}{ Total } & $\begin{array}{l}\text { Frequen } \\
\text { cy }\end{array}$ & 277 & 55 & 64 & 40 & 17 & $3^{45}$ \\
\hline & $\%$ & $61.1 \%$ & $12.1 \%$ & $14.1 \%$ & $8.8 \%$ & $3.8 \%$ & $\begin{array}{r}10 \\
0.0 \% \\
\end{array}$ \\
\hline \multirow{2}{*}{$\begin{array}{c}\text { Manufacturin } \\
\mathrm{g}\end{array}$} & $\begin{array}{l}\text { Frequen } \\
\text { cy }\end{array}$ & 144 & 29 & 23 & 15 & 10 & $1^{22}$ \\
\hline & $\%$ & $65.2 \%$ & $13.1 \%$ & $10.4 \%$ & $6.8 \%$ & $4.5 \%$ & $\begin{array}{r}10 \\
0.0 \% \\
\end{array}$ \\
\hline \multirow{2}{*}{$\begin{array}{l}\text { Service } \\
\text { industry }\end{array}$} & $\begin{array}{l}\text { Frequen } \\
\text { сy }\end{array}$ & 50 & 5 & 8 & 6 & 3 & 72 \\
\hline & $\%$ & $69.4 \%$ & $6.9 \%$ & $11.1 \%$ & $8.3 \%$ & $4.2 \%$ & $\begin{array}{r}10 \\
0.0 \%\end{array}$ \\
\hline \multirow{2}{*}{ Construction } & $\begin{array}{l}\text { Frequen } \\
\text { cy }\end{array}$ & 23 & 3 & 14 & 3 & 1 & 44 \\
\hline & $\%$ & $52.3 \%$ & $6.8 \%$ & $31.8 \%$ & $6.8 \%$ & $2.3 \%$ & $\begin{array}{r}10 \\
0.0 \%\end{array}$ \\
\hline \multirow{2}{*}{$\begin{array}{l}\text { Industrial } \\
\text { accident } \\
\text { prevention } \\
\text { organization }\end{array}$} & $\begin{array}{l}\text { Frequen } \\
\text { cy }\end{array}$ & 18 & 4 & 6 & 10 & 1 & 39 \\
\hline & $\%$ & $46.2 \%$ & $10.3 \%$ & $15.4 \%$ & $25.6 \%$ & $2.6 \%$ & $\begin{array}{r}10 \\
0.0 \%\end{array}$ \\
\hline \multirow{2}{*}{$\begin{array}{c}\text { Safety and } \\
\text { health education } \\
\text { institution }\end{array}$} & $\begin{array}{l}\text { Frequen } \\
\text { сy }\end{array}$ & 7 & 1 & 3 & 1 & 0 & 12 \\
\hline & $\%$ & $58.3 \%$ & $8.3 \%$ & $25.0 \%$ & $8.3 \%$ & $.0 \%$ & $\begin{array}{r}10 \\
0.0 \%\end{array}$ \\
\hline \multirow{2}{*}{ Other } & $\begin{array}{l}\text { Frequen } \\
\text { cy }\end{array}$ & 35 & 13 & 10 & 5 & 2 & 65 \\
\hline & $\%$ & $53.8 \%$ & $20.0 \%$ & $15.4 \%$ & $7.7 \%$ & $3.1 \%$ & $\begin{array}{r}10 \\
0.0 \% \\
\end{array}$ \\
\hline \multicolumn{8}{|c|}{ Pearson's chi-square $=39.002 * * / p=.007$} \\
\hline
\end{tabular}

$* * p<.01$

\subsubsection{Important Competencies Required of Business Owners}

The selection of educational contents is very important to increase the effectiveness of safety and health education for business owners and its relevance to workplaces. Therefore, the job and basic competencies that are perceived to be important to business owners were identified through the survey.

a.Perception of Important Job Competencies Required of Business Owners

Among employers' job competencies, the competency related to the "economic value of losses due to accidents" received the average rating (standard deviation) of $3.81(.858)$, which indicates that the respondents put the greatest importance on this competency.

As a result of analyzing the differences in the perception of business owners' important job competencies depending on the general characteristics of the study subjects, it was found that the general characteristics excluding age and size of the workplace led to the statistically significant differences in the average score of each group's perception of these competencies. In respect to age, the respondents in their 20 s received the highest average score (standard deviation) of 3.90 (.682) regarding the perception of business owners' important job competencies, showing a statistically significant difference $(\mathrm{F}=3.26, \mathrm{p}=.012)$ at the significance level of .05 compared to other groups. In terms of the size of the workplace, those working for businesses with 300 to 499 
employees acquired the highest average score (standard deviation) of 3.84 (.768) regarding the perception of business owners' important job competencies. They showed a statistically significant difference $(\mathrm{F}=6.291$, $\mathrm{p}=.000)$ at the significance level of .001 . compared to other groups.

\section{b. Perception of Important Basic Competencies Required of Business Owners}

Among employers' basic competencies, interpersonal relationship skills received the average rating (standard deviation) of 3.76 (.890), which suggests that the respondents consider this competency most important.

As a result of analyzing the differences in the perception of business owners' important basic competencies depending on the general characteristics of the study subjects, it turned out that the general characteristics excluding age, size of the workplace, and position led to the statistically significant differences in the average score of each group's perception of these competencies. In respect to age, the respondents in their 20s received the highest average score (standard deviation) of 3.83 (.597) regarding the perception of business owners' important basic competencies, showing a statistically significant difference $(\mathrm{F}=4.193, \mathrm{p}=.002)$ at the significance level of .01 compared to other groups. In terms of the size of the workplace, those working for businesses with 500 or more employees acquired the highest average score (standard deviation) of 3.77 (.716) regarding the perception of business owners' important basic competencies, with a statistically significant difference $(\mathrm{F}=4.351$, $\mathrm{p}=.006)$ at the significance level of .01 compared to other groups. With regard to position, those in charge of safety and health management gained the highest score of 3.96 (.638) and they had a statistically significant difference $(\mathrm{F}=1.294, \mathrm{p}=.043)$ at the significance level of .05 in comparison with other groups.

When conducting safety and health education for business owners, it is necessary to thoroughly grasp the roles of business owners and apply the frame of safety and health education in an extensive way. In other words, the educational contents should not be confined to the field of safety and health, but address various areas perceived as important as business owners' job and basic competencies, in order to enhance the participation rate of business owners in education and its relevance to workplaces.

<Table 5> Important Job Competencies Required of Business Owners (N=453)

\begin{tabular}{|c|c|c|c|c|}
\hline Competencies Required of Business Owners & $\begin{array}{l}\text { Skew } \\
\text { ness }\end{array}$ & $\begin{array}{l}\text { Kurt } \\
\text { osis }\end{array}$ & $\begin{array}{l}\text { M } \\
\text { ean }\end{array}$ & $\begin{array}{l}\text { Standard } \\
\text { deviation }\end{array}$ \\
\hline $\begin{array}{l}\text { (1) Understanding of government policies related to } \\
\text { safety and health }\end{array}$ & -.029 & $\begin{array}{r}- \\
.457\end{array}$ & 67 & .919 \\
\hline $\begin{array}{l}\text { (2) Understanding of laws related tooccupational safety } \\
\text { and health }\end{array}$ & -.181 &. & 60 & .969 \\
\hline $\begin{array}{l}\text { (3) Competency related to the economic value of losses } \\
\text { due to accidents }\end{array}$ & .110 & $\begin{array}{r}- \\
1.142\end{array}$ & 81. & .858 \\
\hline $\begin{array}{l}\text { (4) Competency related to partner and supplier } \\
\text { management }\end{array}$ & .102 &. & 60 & .866 \\
\hline (5) Understanding of safety culture & -.108 & .550 & 72 & .927 \\
\hline (6) Understanding of safety management system & -.151 & .248 & 62 & .942 \\
\hline
\end{tabular}

> Differences in the Perception of Important Job Competencies Depending on the General Characteristics of the Respondents $(\mathrm{N}=453)$

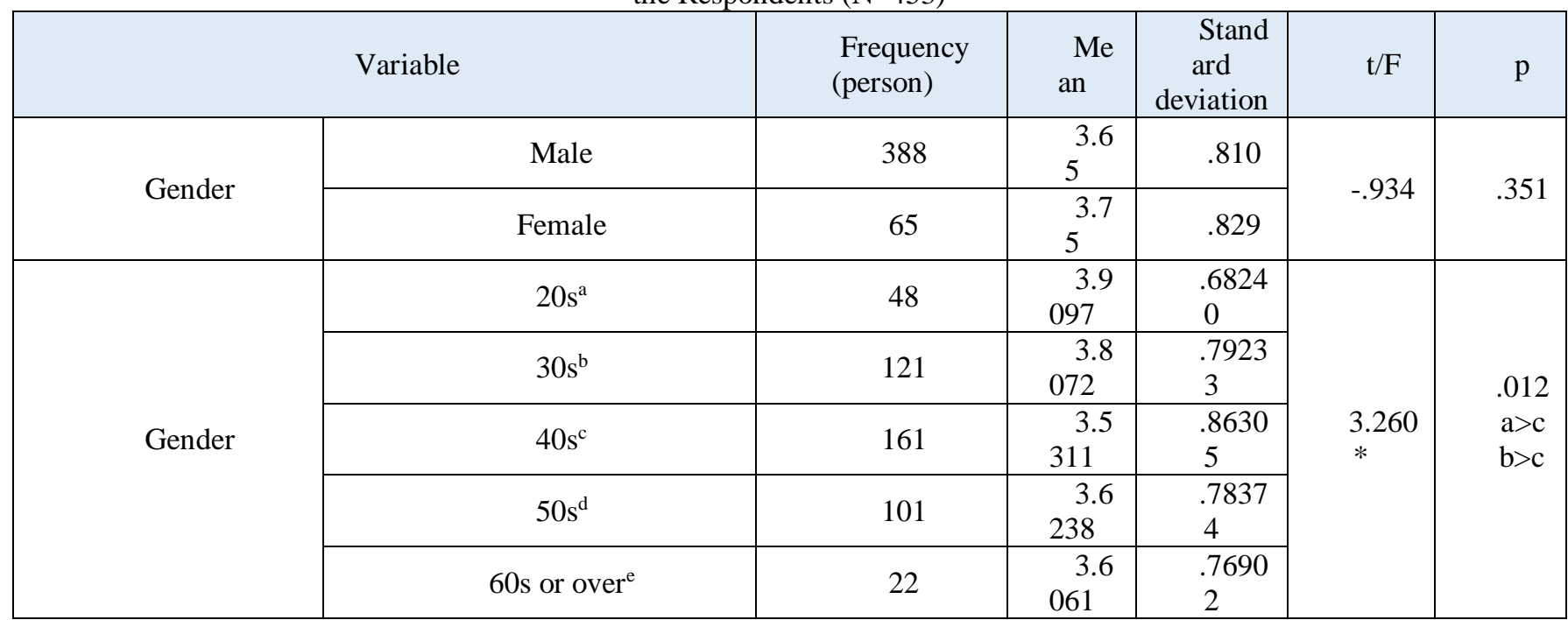




\begin{tabular}{|c|c|c|c|c|c|c|}
\hline \multirow{6}{*}{ Business category } & Manufacturing & 221 & $\begin{array}{l}3.6 \\
493\end{array}$ & $\begin{array}{l}.7903 \\
0\end{array}$ & \multirow{6}{*}{.917} & \multirow{6}{*}{.469} \\
\hline & Service industry & 72 & $\begin{array}{l}3.7 \\
685\end{array}$ & $\begin{array}{l}.8357 \\
0\end{array}$ & & \\
\hline & Construction & 44 & $\begin{array}{r}3.7 \\
614\end{array}$ & $\begin{array}{l}.8239 \\
0\end{array}$ & & \\
\hline & $\begin{array}{c}\text { Industrial accident } \\
\text { prevention organization }\end{array}$ & 39 & $\begin{array}{l}3.4 \\
530\end{array}$ & $\begin{array}{l}.8651 \\
4\end{array}$ & & \\
\hline & $\begin{array}{l}\text { Safety and health education } \\
\text { institution }\end{array}$ & 12 & $\begin{array}{c}3.7 \\
083\end{array}$ & $\begin{array}{l}.4930 \\
1\end{array}$ & & \\
\hline & Other & 65 & $\begin{array}{l}3.6 \\
872\end{array}$ & $\begin{array}{l}.8692 \\
8\end{array}$ & & \\
\hline \multirow{4}{*}{$\begin{array}{l}\text { Size of the } \\
\text { workplace } \\
\text { (number of } \\
\text { employees) }\end{array}$} & 1-49 employees ${ }^{\mathrm{a}}$ & 149 & $\begin{array}{c}3.4 \\
519\end{array}$ & $\begin{array}{l}.7820 \\
5\end{array}$ & \multirow{4}{*}{$\begin{array}{l}6.291 \\
* * *\end{array}$} & \multirow{4}{*}{$\begin{array}{l}.000 \\
\mathrm{a}<\mathrm{d}\end{array}$} \\
\hline & 50-299 employees ${ }^{\mathrm{b}}$ & 124 & $\begin{array}{l}3.6 \\
895\end{array}$ & $\begin{array}{l}.8322 \\
0\end{array}$ & & \\
\hline & 300-499 employees ${ }^{\mathrm{c}}$ & 41 & $\begin{array}{l}3.8 \\
415\end{array}$ & $\begin{array}{l}.7682 \\
5\end{array}$ & & \\
\hline & 500 or more employees ${ }^{\mathrm{d}}$ & 139 & $\begin{array}{c}3.8 \\
333 \\
\end{array}$ & $\begin{array}{l}.7955 \\
2 \\
\end{array}$ & & \\
\hline \multirow{5}{*}{ Position } & Management supervisor & 198 & $\begin{array}{c}3.5 \\
968 \\
\end{array}$ & $\begin{array}{l}.7813 \\
9\end{array}$ & \multirow{5}{*}{1.383} & \multirow{5}{*}{.239} \\
\hline & Safety and health manager & 125 & $\begin{array}{c}3.7 \\
467\end{array}$ & $\begin{array}{l}.8028 \\
3\end{array}$ & & \\
\hline & $\begin{array}{l}\text { Person in charge of safety } \\
\text { and healthmanagement }\end{array}$ & 13 & $\begin{array}{c}3.8 \\
077\end{array}$ & $\begin{array}{l}.8356 \\
8\end{array}$ & & \\
\hline & Business owners & 8 & $\begin{array}{c}3.2 \\
708 \\
\end{array}$ & $\begin{array}{l}.4623 \\
7 \\
\end{array}$ & & \\
\hline & Other & 109 & $\begin{array}{l}3.7 \\
248\end{array}$ & $\begin{array}{l}.8869 \\
7\end{array}$ & & \\
\hline
\end{tabular}

$* p<.05, * * * p<.001$

<Table 7> Important Basic Competencies Required of Business Owners (N=453)

\begin{tabular}{|c|c|c|c|c|}
\hline Basic Competencies Required of Business Owners & $\begin{array}{l}\text { Skew } \\
\text { ness }\end{array}$ & $\begin{array}{l}\text { Kurt } \\
\text { osis }\end{array}$ & $\begin{array}{l}\text { M } \\
\text { ean }\end{array}$ & $\begin{array}{l}\text { Standard } \\
\text { deviation }\end{array}$ \\
\hline $\begin{array}{l}7 \text { Communication skills (skills related to understanding and } \\
\text { preparing documents, ability to listen attentively, linguistic ability) }\end{array}$ & .107 &. & 71 & .879 \\
\hline $\begin{array}{l}8 \text { Mathematical skills (basic calculation and statistics, chart } \\
\text { analysis and creation) }\end{array}$ & .388 & .056 & 43 & .795 \\
\hline (9) Problem solving ability (thinking ability, problem handling) & .150 & .543 & 65 & .864 \\
\hline $\begin{array}{l}10 \text { Self-development ability (self-awareness, self-management, } \\
\text { career development) }\end{array}$ & .220 & .472 & 60 & .858 \\
\hline $\begin{array}{l}\text { 11) Resource management capacity (management of time, budget, } \\
\text { material and human resources) }\end{array}$ & .204 & .591 & 64 & .848 \\
\hline $\begin{array}{l}12 \text { Interpersonal relationship skills (teamwork, leadership, conflict } \\
\text { management) }\end{array}$ & .089 & $\begin{array}{r}- \\
1.009\end{array}$ & 76 & .890 \\
\hline $\begin{array}{l}13 \text { Information handling ability (computer skills, information } \\
\text { processing) }\end{array}$ & .435 & .095 & 42 & .801 \\
\hline $\begin{array}{l}\text { (14) Technical capacity (understanding of technology, selection of } \\
\text { technology, adaptation to new technology) }\end{array}$ & .301 & .299 & 59 & .814 \\
\hline $\begin{array}{l}\text { (15) Understanding of the organization (international mindset, } \\
\text { understanding of organizational system and management, } \\
\text { understanding of different jobs) }\end{array}$ & .050 & .888 & 75 & .902 \\
\hline (16) Occupational ethics (work ethics, community ethics) & .051 & .835 & $\begin{array}{c}3 . \\
74\end{array}$ & .910 \\
\hline
\end{tabular}


<Table 8> Differences in the Perception of Important Basic Competencies Depending on the General Characteristics of the Respondents $(\mathrm{N}=453)$

\begin{tabular}{|c|c|c|c|c|c|c|}
\hline & Variable & $\begin{array}{c}\text { Freque } \\
\text { ncy } \\
\text { (person) } \\
\end{array}$ & $\begin{array}{l}\text { M } \\
\text { ean }\end{array}$ & $\begin{array}{c}\text { Stand } \\
\text { ard } \\
\text { deviation } \\
\end{array}$ & $\mathrm{t} / \mathrm{F}$ & $\mathrm{p}$ \\
\hline \multirow{2}{*}{ Gender } & Male & 388 & $\begin{array}{l}3.6 \\
1 \\
\end{array}$ & .709 & \multirow{2}{*}{1.076} & \multirow{2}{*}{$83^{.2}$} \\
\hline & Female & 65 & $\begin{array}{l}3.7 \\
1\end{array}$ & .820 & & \\
\hline \multirow{5}{*}{ Age } & $20 \mathrm{~s}^{\mathrm{a}}$ & 48 & $\begin{array}{l}3.8 \\
375 \\
\end{array}$ & $\begin{array}{l}.5973 \\
8 \\
\end{array}$ & \multirow{5}{*}{$\begin{array}{l}4.19 \\
3 * *\end{array}$} & \multirow{5}{*}{$\begin{array}{l}02^{.0} \\
>\mathrm{b}\end{array}$} \\
\hline & $30 s^{b}$ & 121 & $\begin{array}{r}3.7 \\
835\end{array}$ & $\begin{array}{l}.7380 \\
5\end{array}$ & & \\
\hline & $40 s^{c}$ & 161 & $\begin{array}{l}3.5 \\
000\end{array}$ & $\begin{array}{l}.7284 \\
4\end{array}$ & & \\
\hline & $50 s^{d}$ & 101 & $\begin{array}{l}3.5 \\
356\end{array}$ & $\begin{array}{l}.7435 \\
8\end{array}$ & & \\
\hline & 60s or over ${ }^{\mathrm{e}}$ & 22 & $\begin{array}{c}3.6 \\
909\end{array}$ & $\begin{array}{l}.6117 \\
2\end{array}$ & & \\
\hline \multirow{6}{*}{$\begin{array}{l}\text { Business } \\
\text { category }\end{array}$} & Manufacturing & 221 & $\begin{array}{l}3.6 \\
032\end{array}$ & $\begin{array}{l}.6858 \\
6\end{array}$ & \multirow{6}{*}{$\begin{array}{l}1.34 \\
9\end{array}$} & \multirow{6}{*}{$42^{.2}$} \\
\hline & Service industry & 72 & $\begin{array}{c}3.7 \\
417\end{array}$ & $\begin{array}{l}.7834 \\
1\end{array}$ & & \\
\hline & Construction & 44 & $\begin{array}{c}3.7 \\
545\end{array}$ & $\begin{array}{l}.7209 \\
3 \\
\end{array}$ & & \\
\hline & $\begin{array}{l}\text { Industrial accident prevention } \\
\text { organization }\end{array}$ & 39 & $\begin{array}{c}3.4 \\
154\end{array}$ & $\begin{array}{l}.7600 \\
3\end{array}$ & & \\
\hline & $\begin{array}{l}\text { Safety and health education } \\
\text { institution }\end{array}$ & 12 & $\begin{array}{l}3.6 \\
000\end{array}$ & $\begin{array}{l}.5152 \\
2\end{array}$ & & \\
\hline & Other & 65 & $\begin{array}{l}3.6 \\
385 \\
\end{array}$ & $\begin{array}{l}.8001 \\
4 \\
\end{array}$ & & \\
\hline \multirow{4}{*}{$\begin{array}{l}\text { Size of the } \\
\text { workplace } \\
\text { (number of } \\
\text { employees) }\end{array}$} & 1-49 employees ${ }^{\mathrm{a}}$ & 149 & $\begin{array}{l}3.4 \\
725\end{array}$ & $\begin{array}{l}.7193 \\
1\end{array}$ & \multirow{4}{*}{$\begin{array}{l}4.35 \\
1 * *\end{array}$} & \multirow{4}{*}{$\begin{array}{c}06^{.0} \\
>a^{d}\end{array}$} \\
\hline & 50-299 employees ${ }^{\mathrm{b}}$ & 124 & $\begin{array}{l}3.6 \\
371 \\
\end{array}$ & $\begin{array}{l}.7362 \\
3 \\
\end{array}$ & & \\
\hline & 300-499 employees ${ }^{\mathrm{c}}$ & 41 & $\begin{array}{l}3.6 \\
902\end{array}$ & $\begin{array}{l}.6733 \\
5\end{array}$ & & \\
\hline & 500 or more employees ${ }^{\mathrm{d}}$ & 139 & $\begin{array}{l}3.7 \\
705\end{array}$ & $\begin{array}{l}.7164 \\
2\end{array}$ & & \\
\hline \multirow{5}{*}{ Position } & Management supervisor ${ }^{a}$ & 198 & $\begin{array}{l}3.5 \\
343\end{array}$ & $\begin{array}{l}.6846 \\
6\end{array}$ & \multirow{5}{*}{$\begin{array}{l}1.29 \\
4^{*}\end{array}$} & \multirow{5}{*}{$\begin{array}{c}43^{0} \\
\text { b } \\
>c, \\
<e^{c}\end{array}$} \\
\hline & Safety and health manager ${ }^{b}$ & 125 & $\begin{array}{c}3.7 \\
352\end{array}$ & $\begin{array}{l}.6776 \\
7\end{array}$ & & \\
\hline & $\begin{array}{l}\text { Person in charge of safety and } \\
\text { health management }{ }^{\mathrm{c}}\end{array}$ & 13 & $\begin{array}{r}3.9 \\
692 \\
\end{array}$ & $\begin{array}{l}.6382 \\
1 \\
\end{array}$ & & \\
\hline & Business owners ${ }^{\mathrm{d}}$ & 8 & $\begin{array}{l}3.4 \\
000\end{array}$ & $\begin{array}{l}.5209 \\
9\end{array}$ & & \\
\hline & Other $^{\mathrm{e}}$ & 109 & $\begin{array}{c}3.6 \\
541 \\
\end{array}$ & $\begin{array}{l}.8473 \\
9\end{array}$ & & \\
\hline
\end{tabular}




\subsubsection{Perception of Adequate Education Cycle}

$<$ Table 9 $>$ shows the survey results on the respondents' perception of the adequate cycle of safety and health education for business owners.

Regarding the cycle of safety and health education for business owners, 187 respondents selected "regular education on an annual basis," accounting for the largest proportion (41.3\%) of the total.

Among the general characteristics, gender and age were the factors that led to statistically significant differences in the perception of the safety and health education cycle for business owners between groups. With regard to gender, the view that regular education on an annual basis needs to be adopted was more prominent in the female group than in the male group. In terms of age, the group in their 30 s chose "regular education on an annual basis" with the highest percentage.
$<$ Table 9> Adequate Cycle of Safety and Health Education for Business Owners $(\mathrm{N}=453)$

\begin{tabular}{|c|c|c|}
\hline Education cycle & Frequency (person) & Percentage (\%) \\
\hline $\begin{array}{c}\text { Regular education } \\
\text { on an annual basis }\end{array}$ & 187 & 41.3 \\
\hline $\begin{array}{c}\text { Regular education } \\
\text { on a biennial basis }\end{array}$ & 153 & 33.8 \\
\hline $\begin{array}{c}\text { Regular education } \\
\text { every 3 years }\end{array}$ & 105 & 23.2 \\
\hline $\begin{array}{c}\text { Regular training } \\
\text { every 5 years }\end{array}$ & 3 & .7 \\
\hline $\begin{array}{c}\text { One-off education } \\
\text { after the } \\
\text { establishment of } \\
\text { the business } \\
\text { (within a year } \\
\text { after business } \\
\text { registration) }\end{array}$ & 5 & 1.1 \\
\hline
\end{tabular}

$<$ Table 10 > Differences in the Perception of Safety and Health Education Cycle for Business Owners Depending on Gender (N=453)

\begin{tabular}{|c|c|c|c|c|c|c|c|}
\hline \multirow{2}{*}{ Gender } & Classification & $\begin{array}{c}\text { Regular } \\
\text { education on } \\
\text { an annual } \\
\text { basis }\end{array}$ & $\begin{array}{c}\text { Regular } \\
\text { education on a } \\
\text { biennial basis }\end{array}$ & $\begin{array}{c}\text { Regular } \\
\text { education every } \\
3 \text { years }\end{array}$ & $\begin{array}{c}\text { One-off } \\
\text { Regular } \\
\text { education every } \\
5 \text { years } \\
\text { education after } \\
\text { the } \\
\text { establishment } \\
\text { of the business }\end{array}$ & Total \\
\hline \multirow{2}{*}{ Total } & Frequency & 187 & 153 & 105 & 3 & 5 & 453 \\
\cline { 2 - 9 } & $\%$ & $41.3 \%$ & $33.8 \%$ & $23.2 \%$ & $.7 \%$ & $1.1 \%$ & $100.0 \%$ \\
\hline \multirow{2}{*}{ Male } & Frequency & 158 & 131 & 94 & 3 & 2 & 388 \\
\cline { 2 - 9 } & $\%$ & $40.7 \%$ & $33.8 \%$ & $24.2 \%$ & $.8 \%$ & $3 \%$ & $100.0 \%$ \\
\hline \multirow{2}{*}{ Female } & Frequency & 29 & 22 & 11 & 0 & 3 & 65 \\
\cline { 2 - 9 } & $\%$ & $44.6 \%$ & $33.8 \%$ & $16.9 \%$ & $.0 \%$ & $4.6 \%$ & $100.0 \%$ \\
\hline
\end{tabular}

$* p<.05$

$<$ Table 11 > Differences in the Perception of Safety and Health Education Cycle for Business Owners Depending on Age

\begin{tabular}{|c|c|c|c|c|c|c|c|}
\hline Age & Classification & $\begin{array}{c}\text { Regular } \\
\text { education on } \\
\text { an annual } \\
\text { basis }\end{array}$ & $\begin{array}{c}\text { Regular } \\
\text { education on a } \\
\text { biennial basis }\end{array}$ & $\begin{array}{c}\text { Regular } \\
\text { education } \\
\text { every } 3 \text { years }\end{array}$ & $\begin{array}{l}\text { Regular education } \\
\text { every } 5 \text { years }\end{array}$ & $\begin{array}{l}\text { One-off education after } \\
\text { the establishment of the } \\
\text { business }\end{array}$ & Total \\
\hline \multirow{2}{*}{ Total } & Frequency & 187 & 153 & 105 & 3 & 5 & 453 \\
\hline & $\%$ & $41.3 \%$ & $33.8 \%$ & $23.2 \%$ & $.7 \%$ & $1.1 \%$ & $100.0 \%$ \\
\hline \multirow{2}{*}{$20 \mathrm{~s}$} & Frequency & 16 & 21 & 8 & 0 & 3 & 48 \\
\hline & $\%$ & $33.3 \%$ & $43.8 \%$ & $16.7 \%$ & $.0 \%$ & $6.3 \%$ & $100.0 \%$ \\
\hline \multirow{2}{*}{$30 \mathrm{~s}$} & Frequency & 61 & 35 & 24 & 1 & 0 & 121 \\
\hline & $\%$ & $50.4 \%$ & $28.9 \%$ & $19.8 \%$ & $.8 \%$ & $.0 \%$ & $100.0 \%$ \\
\hline \multirow{2}{*}{$40 \mathrm{~s}$} & Frequency & 65 & 53 & 42 & 1 & 0 & 161 \\
\hline & $\%$ & $40.4 \%$ & $32.9 \%$ & $26.1 \%$ & $.6 \%$ & $.0 \%$ & $100.0 \%$ \\
\hline \multirow{2}{*}{$50 \mathrm{~s}$} & Frequency & 40 & 36 & 22 & 1 & 2 & 101 \\
\hline & $\%$ & $39.6 \%$ & $35.6 \%$ & $21.8 \%$ & $1.0 \%$ & $2.0 \%$ & $100.0 \%$ \\
\hline \multirow{2}{*}{$\begin{array}{c}60 \mathrm{~s} \\
\text { or } \\
\text { over }\end{array}$} & Frequency & 5 & 8 & 9 & 0 & 0 & 22 \\
\hline & $\%$ & $22.7 \%$ & $36.4 \%$ & $40.9 \%$ & $.0 \%$ & $.0 \%$ & $100.0 \%$ \\
\hline
\end{tabular}




\section{Conclusions}

This study conducted a survey for occupational safety and health officials in order to provide data for discussion on the introduction of safety and health education system for business owners. Based on the survey results, this study comprehensively analyzed the officials' expectation level on industrial accident prevention effect by the introduction of such system, their perception of competencies required of business owners, the target group of education, and adequate education cycle. The results of the analysis are as follows.

(1) According to the survey results on the officials' expectation level on industrial accident prevention effect by the introduction of safety and health education system for business owners, $86.7 \%$ of the respondents had a positive view toward the effect. This shows that such system is considered essential in enhancing the safety and health environment and awareness of workplaces. Therefore, it needs to actively promote the introduction of safety and health education system for business owners to reduce industrial accidents.

(2) The analysis of the survey results on the perception of business owners' important job and basic competencies showed that the respondents put the greatest importance on competency related to the economic value of losses due to accidents among job competencies and interpersonal relationship skills among basic competencies. This suggests that an effective curriculum be developed as safety and health education for business owners needs to include contents that can help business owners to strengthen such competencies.

(3) As a result of analyzing the respondents' perception of the target group of safety and health education for business owners, the largest proportion $(61.1 \%)$ of the study subjects selected "business owners at all workplaces." Inaddition, in terms of education cycle, it was "regular education on an annual basis" that the largest percentage $(41.3 \%)$ of respondents chose. To be short, the respondents prefer that regular education will be carried out every year for business owners at all types of workplaces.

\section{References}

1. The Ministry of Employment and Labor. (2009). Analysis of industrial accidents in the year 2008

2. The Ministry of Employment and Labor. (2019). Analysis of industrial accidents in the year 2018.

3. Konghwa Jang, Kwonchul Ha. (2016). The Effect of Occupational Safety and Health Education on Occupational Accidents. Journal of Korean Society of Occupational and Environmental Hygiene, 26(1), 90-98

4. Jong Cheol Kang, Seong Rok Chang. (2005). Promoting Effectiveness of Occupational Health and Safety Education Program. Journal of the KOSOS, 20(1), 143-147.

5. Gun-Hee Kim, Myung-Jin Jung, Tae-hee Kim.(2019). A Study on the Prevention of Fall Accidents for Elderly Workers. The Journal of the Convergence on Culture Technology, 5(4), 349-354.

6. The Ministry of Employment and Labor. Occupational Safety and Health Act, Article 31, 31-2, 32.

7. The Ministry of Employment and Labor. Insurance Collection Law of Employment Insurance and Industrial Accident Compensation Insurance, Article 15.

8. Cho, Hm-Hak. (2013). A Study on a scope of a responsibility of a employer in OSHA. The Journal of labor law, 29, 41-70.

9. Adanali, R., \& Mete, A. L. I. M. (2019). The Students' Behaviours at the Instructional Geocaching Applied in Problem-Based Environmental Education. Review of International Geographical Education Online, 9(1), 122-148. 